\title{
Patterns of reef fish assemblage distribution on a Brazilian subtropical rocky shore: an approach to benthic association
}

\author{
Luiza dos Santos Vieira ${ }^{1}$ (D), Victor Bastos Teixeira Lupinacci $^{1}$ (D), Letícia \\ Fernandes Lopes Osório dos Santos ${ }^{1}$, Eduardo Arlé ${ }^{1,2}$ (D) \& Rafael da Rocha \\ Fortes $^{1}$ (D)
}

(1) Universidade Federal do Estado do Rio de Janeiro, Centro de Ciências Biológicas e da Saúde, Instituto de Biociências, Departamento de Ecologia e Recursos Marinhos, Laboratório de Ecologia Bêntica, Avenida Pasteur 458, Urca 22290-240, Rio de Janeiro, Brazil.

E-mail: luizadsantosvieira@gmail.com, rafaelfortes@hotmail.com

(2) German Centre for Integrative Biodiversity Research (iDiv), Halle-Jena-Leipzig, Leipzig, Germany. E-mail: eduardo.arle@idiv.de

Vieira L.S., Lupinacci V.B.T., Santos L.F.L.O., Arlé E. \& Fortes R.R. (2021) Patterns of reef fish assemblage distribution on a Brazilian subtropical rocky shore: an approach to benthic association. Pesquisa $e$ Ensino em Ciências Exatas e da Natureza, 5: e1638. http://dx.doi.org/10.29215/pecen.v5i0.1638

Academic editor: Paulo Roberto Medeiros. Received: 08 September 2020. Accepted: 25 January 2021. Published: 30 January 2021.

Padrões de distribuição espacial em assembleias de peixes recifais: uma abordagem da sua associação com o bentos

Resumo: Os ambientes recifais são caracterizados como formações de fundo consolidado de origem orgânica e/ou inorgânica. Em costões rochosos, fatores bióticos e abióticos determinam a sua biodiversidade. Na praia do Forno, onde o fenômeno da ressurgência ocorre, a assembleia de peixes recifais foi analisada por meio de censo visual. A cobertura bentônica do substrato foi classificada em quatro categorias. $\mathrm{O}$ uso do substrato foi determinado pela abundância relativa das espécies em cada um de seus tipos. Um total de 5414 indivíduos pertencentes a 31 espécies de peixes recifais foi observado. Os resultados demonstraram que a preferência por habitats, caracterizados pela cobertura por organismos bentônicos, foi um fator importante na determinação da composição da assembleia de peixes recifais, em uma microescala. A escolha de um habitat dentre os diversos tipos de substrato, poder ser em sua maior parte explicada pela disponibilidade de recursos alimentares.

Palavras chave: Cobertura bentônica, padrões biogeográficos, interações bióticas, habitat, ictiofauna, costões rochosos.

\begin{abstract}
Reef environments are characterized as any formation with a hard substrate of organic and/or inorganic origin. In rocky shores, abiotic and biotic features determine its biodiversity. At Forno beach, where upwelling phenomenon occurs, the reef fish assemblage was identified by underwater visual census. The benthic coverage was classified in four categories. Substrate preference was determined by the relative abundance of each species on each of the substrate. A total of 5414 individuals of 31 reef fish species were observed. The results demonstrated that the habitat preference, characterized by benthic coverage, was important for the composition of reef fish assemblage on a micro-scale. The choice for a habitat among benthic coverage types could be mainly explained by availability of food resources.
\end{abstract}

Key words: Benthic coverage, biogeographical patterns, biotic interactions, habitat, ichthyofauna, rocky shores. 


\section{Introduction}

Reef environments are characterized as formations with a hard substrate of organic (coral reef) and/or inorganic origin (rocky reefs, rocky shores). Coral reefs are composed mainly by Cnidaria of the subclass Hexacorallia, which form a complex three-dimensional structure. They are distributed in tropical and subtropical zones in shallow waters. In marine systems, coral reefs are recognizable as one of the most diverse ecosystems, being comparable to tropical forests in terrestrial systems (Bellwood \& Meyer 2009; Chaves et al. 2010). Rocky shores and nearshore rocky reefs form extensive habitats along several coastlines, and are made of hard material such as granite, chalk, basalt or limestone (Sivaperuman et al. 2018). Although rocky shores show lower topographic complexity than coral reefs, the observed structural complexity in theses ecosystems sustains a rich ichthyofauna (Ferreira et al. 2001). Fish assemblages have the highest levels of diversity in reefs ecosystems, which account about $25 \%$ of species of marine fishes currently known (Daros et al. 2012).

In the Brazilian coast, rocky reefs extensively occur between Espírito Santo and Santa Catarina States (Anderson et al. 2019) and are the main habitat for the reef biota in southern Brazil (Ferreira et al. 2001). Moreover, the patch between Santa Marta Cape (São Paulo State) and the city of Cabo Frio (Rio de Janeiro State) is considered one of the most important rocky shores of the Brazilian coast (MMA 2002; Moreno \& Rocha 2012). This patch is distinguished by the presence of granitic rocky reefs, and is influenced by warm waters of the Brazil Current and cold waters of the South Atlantic Central Water (SACW) (Acha et al. 2004).

In reef environments, climatic and topographic features induce determination of biodiversity in a large and medium scale, respectively (Fortes \& Absalão 2010). On a small scale, the combination of abiotic (e.g., substratum type, temperature, irradiance and wave action) and biotic conditions (e.g., settlement, recruitment, predation and competition), determines the biodiversity of reef ecosystems (Longo et al. 2015). Because these ecosystems generally occur at the interface of the land and sea, the rocky shores are considered a physically harsh environment due to their exposure to wave action, even between the limits of the subtidal zone. Furthermore, the wave exposure (Fulton \& Bellwood 2004; Longo et al. 2015) together with the tidal range (Kraines et al. 2001; McClanahan \& Kamauskas 2011) and the physical properties of the hard substrate, determine the patterns of settlement and establishment of marine epibenthic organisms (marine invertebrates and algae) on these formations (Sivaperuman et al. 2018).

The reef fish assemblages are linked to the benthic communities that inhabit the rocky shores substrates (Medeiros et al. 2010; Krajewski \& Floeter 2011; Longo et al. 2015; Freitas et al. 2019). On a local scale, the abundance of reef fishes and their consequent competition could be related to consumption of food resources available in these environment substrates (Floeter et al. 2007). In addition, these fishes could be associated with organisms of bottom benthic communities, once the spatial structure promoted by these organisms offers shelter against predation and places for oviposition (Quadros et al. 2019). Thus, knowledge about substrate composition is important to define the structure of reef fish assemblage.

Space competition is a driving force structuring the benthic biota inhabiting the substrate of rocky shores. The structure and and functioning of coral reefs are related to the spatial distribution of fast-growing benthic algae with relatively slow-growing corals (Floeter et al. 2005; Gil et al. 2015). This feature highlights the relative importance of herbivory (top-down force) on the structure of these benthic communities (Floeter et al. 2005; Longo et al. 2015). Thus, herbivorous fishes mediate the competition between benthic algae and corals, limiting the spatial distribution of algae on the rocky shore substrate, which allows the settlement of other organisms. Furthermore, reef fish assemblage is a relevant feature for the structure and resilience of this marine ecosystem (Mumby et al. 2012; Graham et al. 2013), which highlights the need to understand their contribution to the ecosystem structure and functioning (Longo et al. 2015).

Beyond the ecosystem services provided by the Coral reefs, these ecosystems also support the social, cultural, and economic well-being of millions of people around the world (Grafeld et 
al. 2016). Despite their importance, coral reef ecosystems are declining globally due to anthropogenic impacts, as overfishing, pollution, habitat degradation, introduction of invasive species, and climate change (Longo et al. 2015). As the entire ecosystems, the fish assemblage is endangered by direct impact (e.g., overfishing), and by the ecosystem degradation (e.g., pollution). Due to its importance for the ecosystem structure and functioning, even in the absence of indirect impact, the direct impact over this assemblage may disrupt entire environment.

Although coral reefs and rocky shores share similar structural and functional properties, the management and conservation of rocky shores do not receive as much attention, which highlights the importance of studies to improve the knowledge about this ecosystem type. Given the importance that the knowledge about substrate composition has in defining the structure of reef fish assemblage, this study aims to investigate the association of substrate coverage and the fish assemblage inhabiting the shallow waters of a subtidal zone of a rocky shore.

\section{Material and Methods}

\section{Study area}

The study took place in the city of Arraial do Cabo - Rio de Janeiro State, a tropical region located in the southeastern Brazilian coast (Figure 1). The local rocky shores are worldwide known as a biodiversity hotspot (Lima \& Coutinho 2016). In this city, there is a marine protected area named Marine Extractive Reserve of Arraial do Cabo - ResexMar AC - that is a target area for the Coral National Action Plan (MMA/ICMBio 2019). The upwelling phenomenon occurs in this region, acting as a biogeographical barrier for several marine species (Spalding et al. 2007), and promoting increase of nutrient availability that enhances the local primary productivity (Batista et al. 2020). Therefore, this cycle sustains a rich trophic web that characterizes the marine environment of Arraial do Cabo as a target area for the development of research projects and promotion of the local economic development (e.g., fisheries, tourism) (Batista et al. 2020).

The site chosen for this study was the rocky shore located on the left side of Forno beach in a maximum depth of three meters and three meters away from the shore $\left(22.9658^{\circ} \mathrm{S}\right.$, $42.0084^{\circ} \mathrm{W}$ ) (Figure 1). This beach is located inside a sheltered bay and is influenced by an upwelling (Gonzalez-Rodriguez et al. 1992) (Figure 1).

\section{Data}

Data were sampled by three snorkeling divers in January, March, April, and May 2019. A total of 24 transects (six each month) of $40 \mathrm{~m}^{2}(20 \mathrm{~m} \mathrm{x} 02 \mathrm{~m})$ were analyzed and observed twice by each diver, totaling $5760 \mathrm{~m}^{2}$ (Figure 1). The distribution of transects were placed in group of three units to allow a wider sampling effort along this side of the beach sheltered against direct wave action and avoid the waste disposable from the floating restaurant and aquiculture farm (Figure 1).

The reef fish assemblage was observed by underwater visual census identifying as lower taxonomic level as possible, based on a checklist (Ferreira et al. 2001). The pictures of reef fish species were taken using a camera SJCam $^{\circledR}$ HD1080P in order to support an indubious identification. The trophic guild of this fish species was based on Ferreira et al. (2004) and Freitas et al. (2019) classified as carnivore, territorial herbivore, roving herbivore, mobile invertivore, sessile invertivore, omnivore, piscivore, and planktivore (Table 1).

The relative abundance of each substratum type was recorded using an action camera $\left(\right.$ Gopro $\left.^{\circledast}\right)$ at five points along each transect five meters distant from each other (five photos for each transect) using a piece of pipe for scale reference. Then, a frame was taken of each video for an analysis using the software Coral Point Count with Excel extension (CPCe) (Kohler \& Gill 2006). The relative benthic coverage was estimated by labeling 180 random points on each frame according to four labels: algae, zoanthids, rocks and others (Figure 2). 

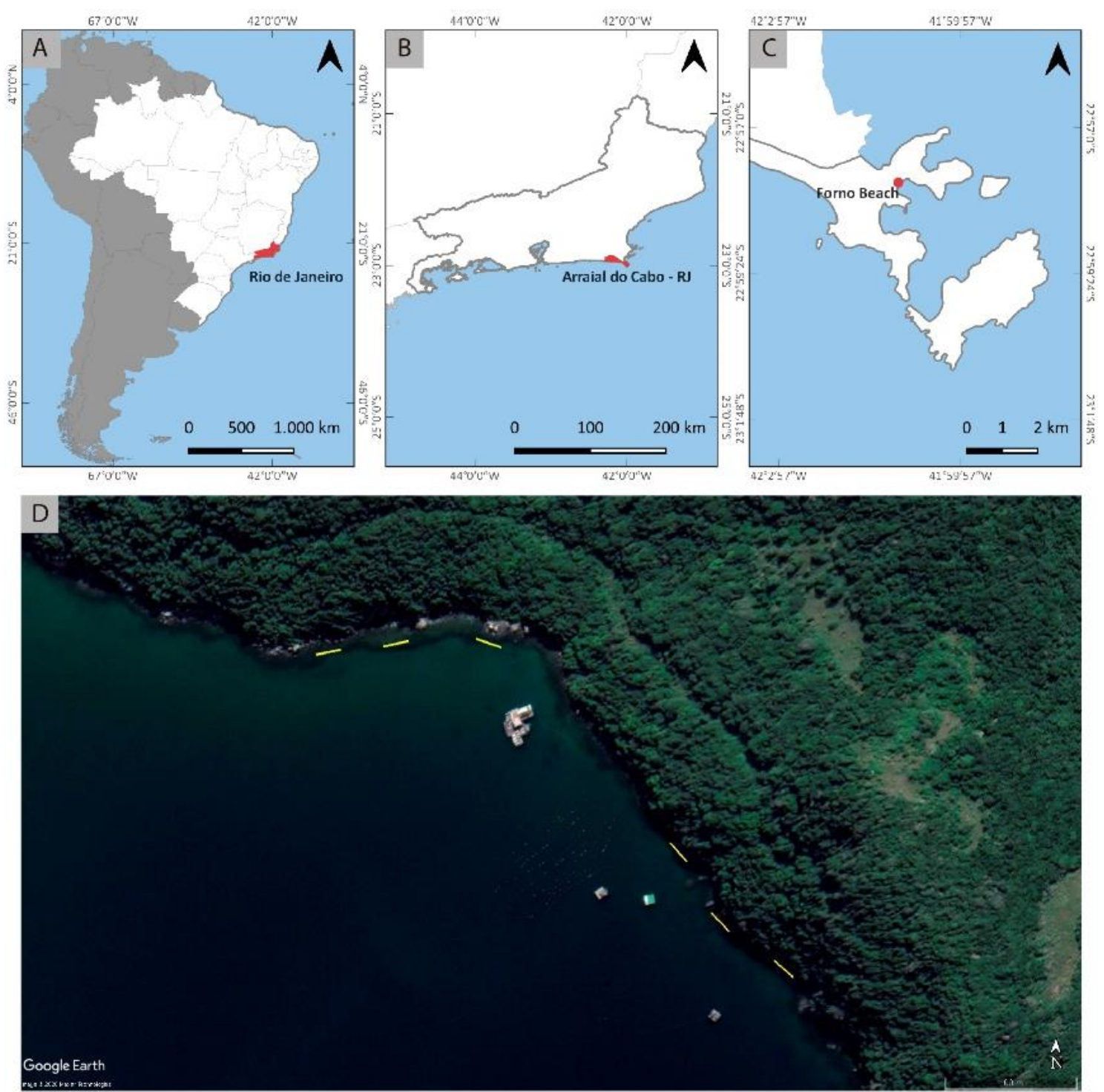

Figure 1. Study area located in the city of Arraial do Cabo - Rio de Janeiro State: A. Vector map of Brazil delimiting Rio de Janeiro; B. Vector map of Rio de Janeiro delimiting Arraial do Cabo-RJ; C. Vector map with a point in Forno beach; D. Satellite image of the left rocky shore of Forno beach, in yellow six sampled transects per campaign, provided by Google Earth Pro (2020). Vector maps were projected using Quantum Gis (2020).

\section{Statistical analysis}

To investigate the influence of substrate benthic composition on fish assemblage composition and trophic guild structure, we performed a redundancy analysis (RDA) considering the entire period, and subsequently for each month separately. To test the RDA significance, we realized a subsequent analysis of variance (ANOVA) of the canonical axes, using the fish assemblage as a response variable and benthic composition as explanatory variable. Adjusted $\mathrm{R}^{2}$ was used to determine the fit of each model. All analyses were performed using the "labdsv" (Roberts 2019) and "vegan" (Oksanen et al. 2013) packages of R software (R Core Team 2019).

Prior to RDA, all explanatory variables were tested for normality (Shapiro-Wilk Test) and collinearity (Pearson's Correlation), considering $|0.7|$ as a remove threshold for the correlation coefficient between each pair of variables (Zuur et al. 2010). Algae and zoanthids coverages were highly correlated (-0.92), thus algae coverage was excluded from all subsequent analysis. Zoanthids and others coverages had approximately-normal distributions thus no transformations were necessary, although rocky coverage was log transformed to meet the 


\section{Reef fish assemblage from Arraial do Cabo}

normality assumption. Furthermore, all explanatory variables were standardized, and fishes' abundances were Hellinger-transformed to account for the presence of rare species and zero values within the dataset.

Table 1. Checklist of reef fishes recorded by this study arranged in taxonomic order within families (Nelson 2006).

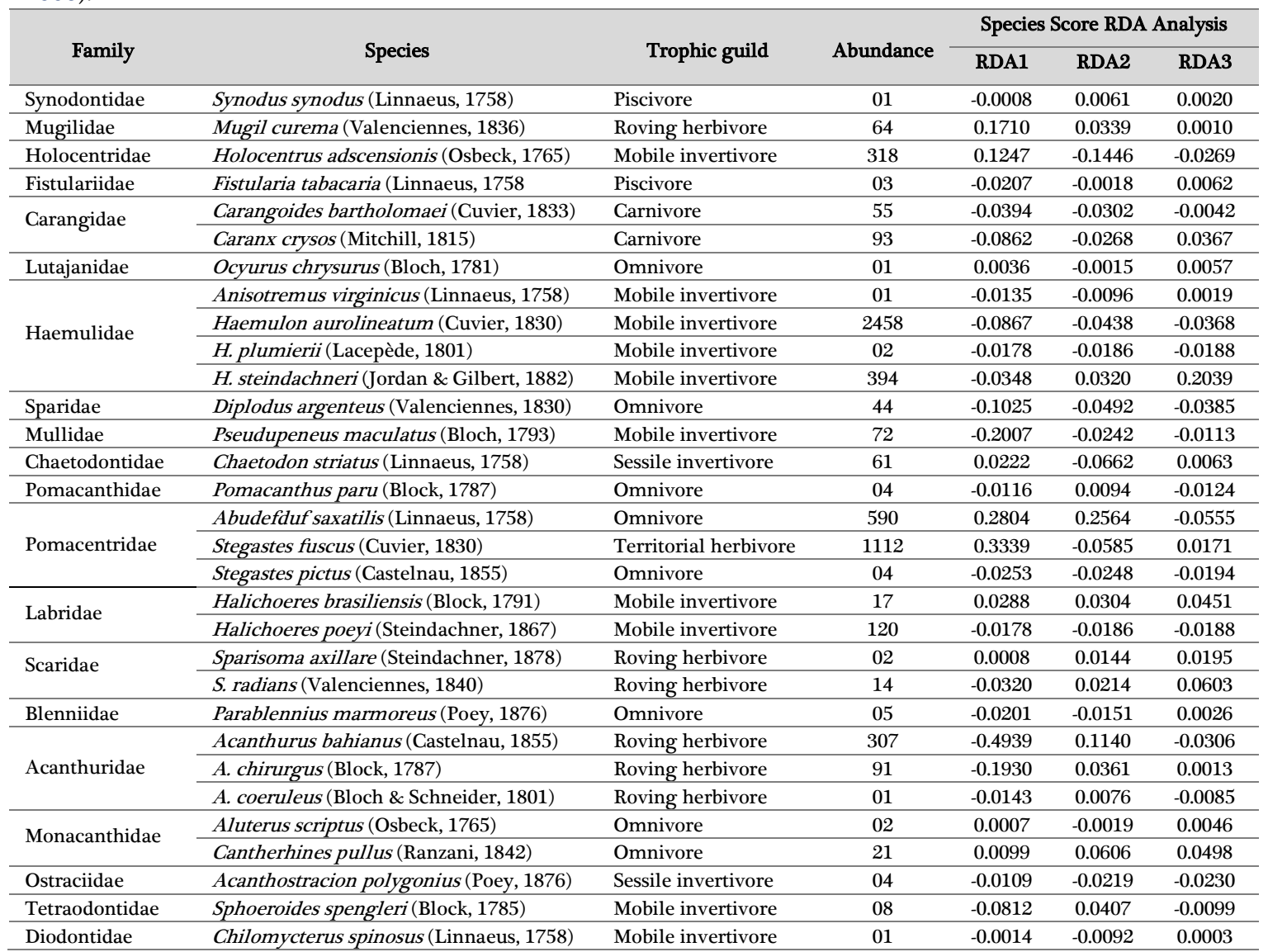
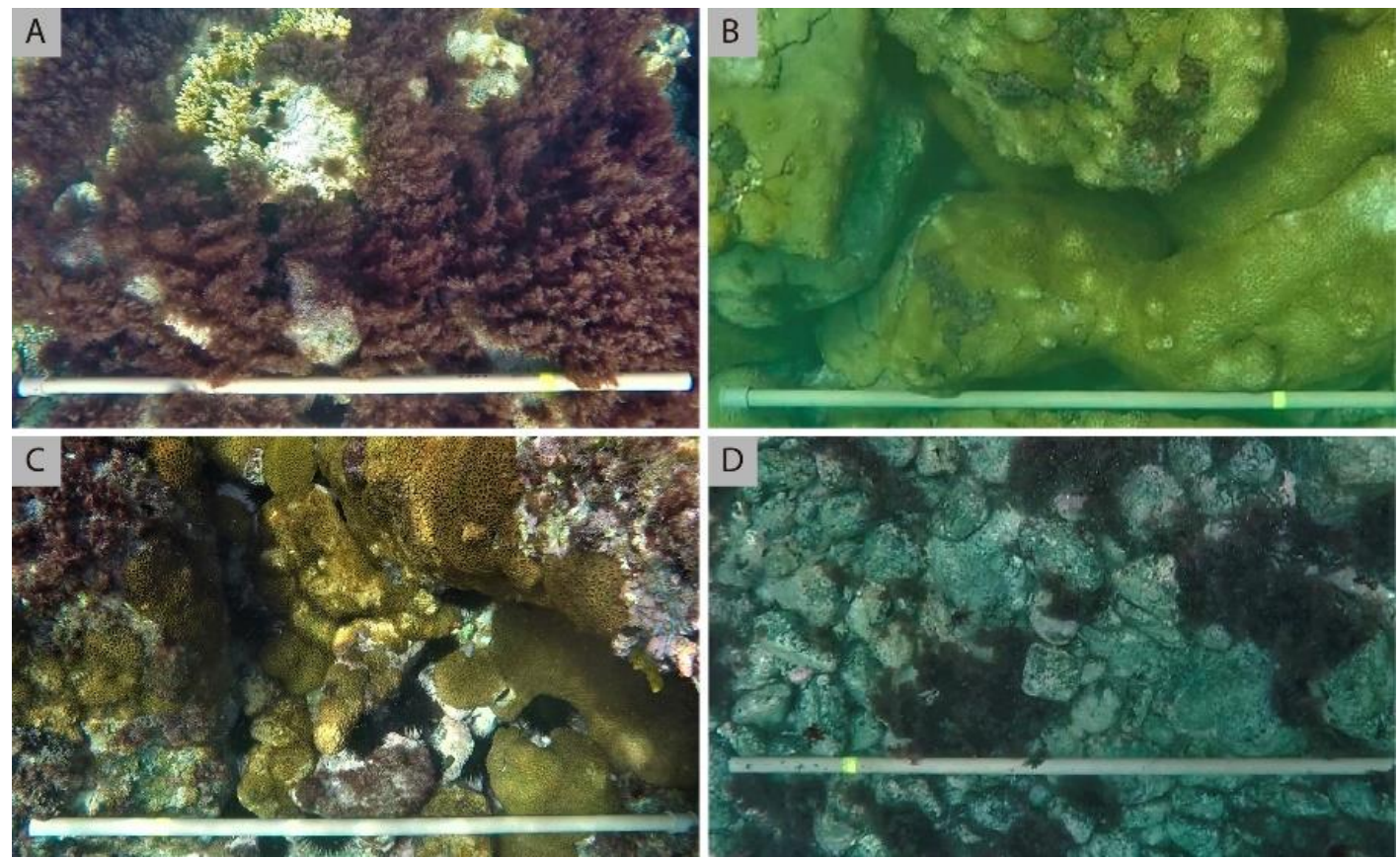

Figure 2. Representative frames of substrates: A. Predominance of algae; B. Predominance of zoanthids; C. Predominance of algae and zoanthids; D. Predominance of algae and rocks. 


\section{Reef fish assemblage from Arraial do Cabo}

\section{Results}

Throughout this study, a total of 5414 individuals of 31 reef fish species belonging to 20 families were observed (Table 1). The species ranked in descending order of abundance were: Haemulon aurolineatum, Stegastes fuscus and Abudefduf saxatilis (Figure 3). Considering all sampling periods, 20 species were classified as uncommon because their abundance was lower than five individuals (Table 1). The specimens of those species were not collected.
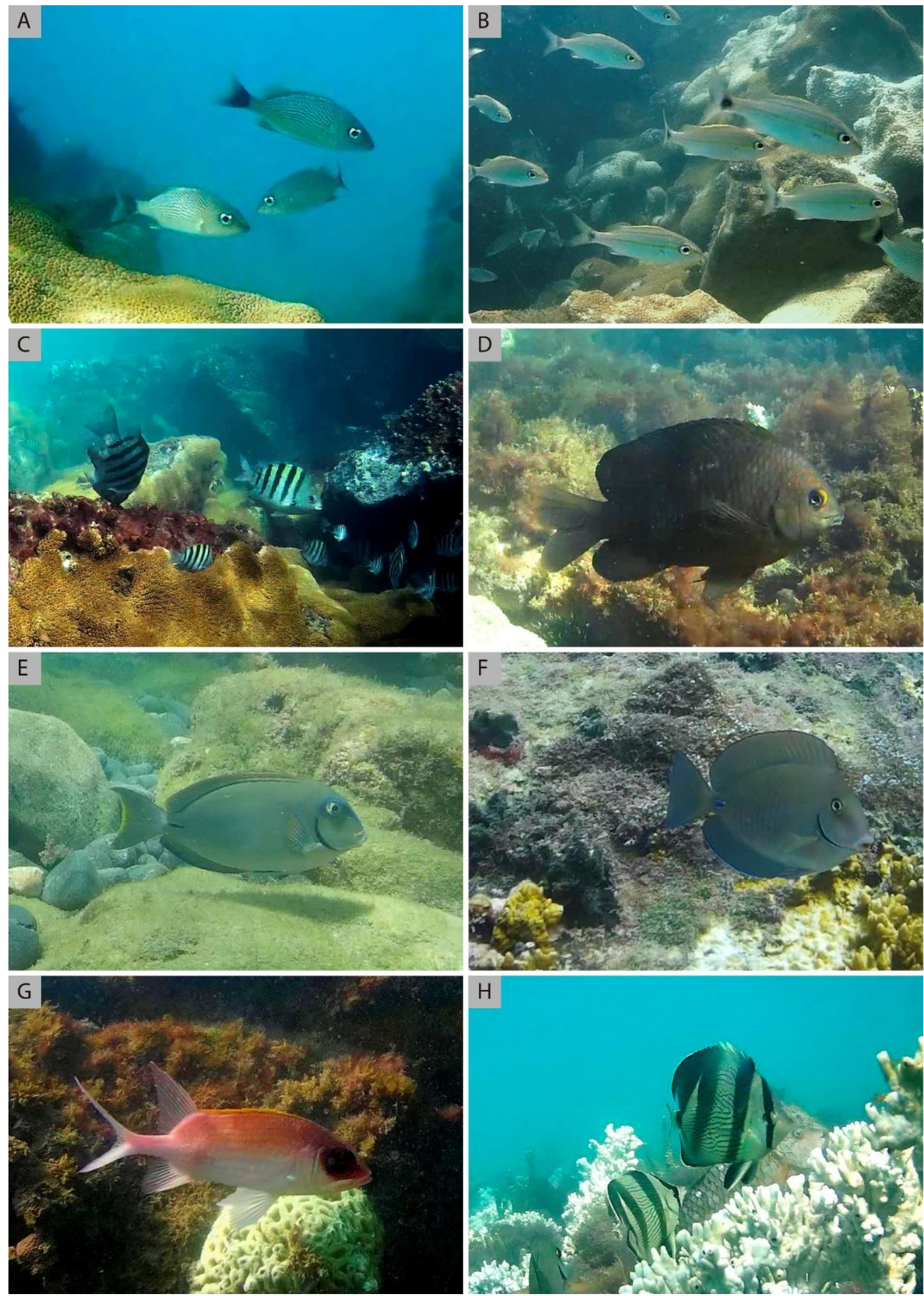

Figure 3. Common reef fish species observed in this study: A. Haemulon steindachneri; B. Haemulon aurolineatum; C. Abudefduf saxatilis; D. Stegastes fuscus; E. Acanthurus bahianus; F. Acanthurus chirurgus; G. Holocentrus adscensionis and H. Chaetodon striatus. 
Benthic cover was characterized on 24 transects, and the main types were zoanthids and algae. Adding all transects, these organisms showed, respectively, mean rates of about $45.66 \%$ and $34.64 \%$. Among these transects, half (12) were mainly covered by zoanthids (mean of $70.57 \%$ ); 6 were mainly covered by algae (mean of $60.67 \%$ ); 4 covered by zoanthids (mean of $41.45 \%$ ) and algae (mean of $41.59 \%$ ) together; and 2 covered by algae (mean of $52.69 \%$ ) and rocks (mean of $42.91 \%$ ) together. Also, the category “others" was not prevalent at any transect.

The redundancy analysis (RDA) of fish assemblages returned three significant axes explaining $17.8 \%$ of the total variation within the species data (adjusted $\mathrm{R}^{2}$ ), with the first and second axes accounted for $21.9 \%$ and $8.7 \%$ (unadjusted $\mathrm{R}^{2}$ ) of the total explained variation (Table 2; Figure 4). Along the RDA, 1 axis (Zoanthids), four species have scores above 0.20 and were considered strongly associated with this axis, Acanthurus bahianus (Castelnau, 1855) (-0.49), $S$. fuscus (0.33), A. saxatilis (0.28) and Pseudupeneus maculatus (Bloch, 1793) (0.20). Along the RDA 2 (Rock) and RDA 3 (others) axes, A. saxatilis (0.26) and Haemulon steindachneri (Jordan $\&$ Gilbert, 1882) (0.20), respectively, were considered strongly associated with these explanatory variables (Table 1; Figure 4).

The RDA of fish assemblages considered each month separately. The results were significant only for April, returning three significant axes explaining $53.2 \%$ of the total variation within the species data (adjusted $\mathrm{R}^{2}$ ), the first and second axes accounted for $57.9 \%$ and $15.5 \%$ unadjusted $\mathrm{R}^{2}$ of the total explained variation (Table 2; Figure 4). Along the RDA 1 axis (zoanthids), four species have scores above 0.20 and were considered strongly associated with this axis, $A$. saxatilis (-0.41), H. aurolineatum (0.40), Holocentrus adscensionis (Osbeck, 1765) (0.33 ) and $S$. fuscus (-0.31) (Table 3; Figure 4). Along the RDA 2 and RDA 3 axes, no species has reached the threshold of the species score value $(0.20)$.

Table 2. Summary of RDA (Redundancy Analysis) analyses to investigate the relationship between substrate coverage and reef fish assemblage and reef fish guilds.

\begin{tabular}{|c|c|c|c|c|c|c|c|c|c|}
\hline \multirow[t]{2}{*}{ Analysis } & \multirow[t]{2}{*}{ Period } & \multirow[t]{2}{*}{$\mathbf{R}_{\text {ajus. }}^{2}$} & \multicolumn{3}{|c|}{$\begin{array}{c}\text { RDA Axis } \\
\text { \% Explained }\end{array}$} & \multirow[b]{2}{*}{ Substrate Coverage } & \multicolumn{3}{|c|}{ RDA Axis Components } \\
\hline & & & 1 & 2 & 3 & & 1 & 2 & 3 \\
\hline \multirow{3}{*}{ Species } & \multirow{3}{*}{ Entire } & \multirow{3}{*}{0.178} & \multirow{3}{*}{0.219} & \multirow{3}{*}{0.045} & \multirow{3}{*}{0.021} & Zoanthids & 0.95 & 0.03 & -0.32 \\
\hline & & & & & & Rocks & -0.58 & 0.81 & 0.11 \\
\hline & & & & & & Others & -0.11 & -0.15 & 0.98 \\
\hline \multirow{3}{*}{ Guild } & \multirow{3}{*}{ Entire } & \multirow{3}{*}{0.222} & \multirow{3}{*}{0.236} & \multirow{3}{*}{0.086} & \multirow{3}{*}{0.002} & Zoanthids & -0.97 & -0.05 & -0.23 \\
\hline & & & & & & Rocks & 0.58 & -0.79 & 0.20 \\
\hline & & & & & & Others & 0.20 & 0.31 & 0.93 \\
\hline \multirow{3}{*}{ Species } & \multirow{3}{*}{ April } & \multirow{3}{*}{0.532} & \multirow{3}{*}{0.579} & \multirow{3}{*}{0.155} & \multirow{3}{*}{0.080} & Zoanthids & -0.85 & 0.18 & 0.51 \\
\hline & & & & & & Rocks & 0.09 & -0.27 & -0.96 \\
\hline & & & & & & Others & 0.72 & -0.51 & -0.48 \\
\hline \multirow{3}{*}{ Guild } & \multirow{3}{*}{ April } & \multirow{3}{*}{0.730} & \multirow{3}{*}{0.662} & \multirow{3}{*}{0.128} & \multirow{3}{*}{0.102} & Zoanthids & 0.73 & 0.68 & -0.05 \\
\hline & & & & & & Rocks & 0.05 & -0.93 & 0.36 \\
\hline & & & & & & Others & -0.53 & -0.82 & -0.22 \\
\hline
\end{tabular}

The RDA of trophic guild structure of fish assemblages returned three significant axes explaining $22.2 \%$ of the total variation within the species data (adjusted $\mathrm{R}^{2}$ ), with the first and second axes accounting for $23.6 \%$ and $4.5 \%$ (unadjusted $\mathrm{R}^{2}$ ) of the total explained variation (Table 2; Figure 5). Along the RDA 1 axis (Zoanthids), three trophic guilds have scores above 0.20 and were considered strongly associated with this axis, roving herbivore $(0.41)$, territorial herbivore (-0.40) and mobile invertivore (0.20). Along the RDA 2 axis (Rock), omnivore (-0.26) and mobile invertivore (0.22) were considered strongly associated with these explanatory variables (Figure 5). Along RDA 3 axis, no guild has reached the threshold of the species score value (0.20).

The RDA of trophic guild structure of fish assemblages, considering each month separately, was significant only for April and returned three significant axes explaining $73.0 \%$ of the total variation within the species data (adjusted $\mathrm{R}^{2}$ ), with the first and second axes accounted 
for $66.2 \%$ and $12.8 \%$ (unadjusted $\mathrm{R}^{2}$ ) of the total explained variation (Table 2; Figure 5). Along the RDA 1 axis (zoanthids), three trophic guilds presented scores above 0.20 and were considered strongly associated with this axis, omnivore (0.45), mobile invertivore $(-0.38)$ and territorial herbivore (0.37). Along the RDA 2 (Rock), roving herbivore (-0.22) was considered strongly associated with these explanatory variables (Figure 5). Along RDA 3 axis, no guild has reached the threshold of the species score value $(0.20)$.

Table 3. Checklist of reef fishes recorded by this study in April, arranged in taxonomic order within families (Nelson 2006).

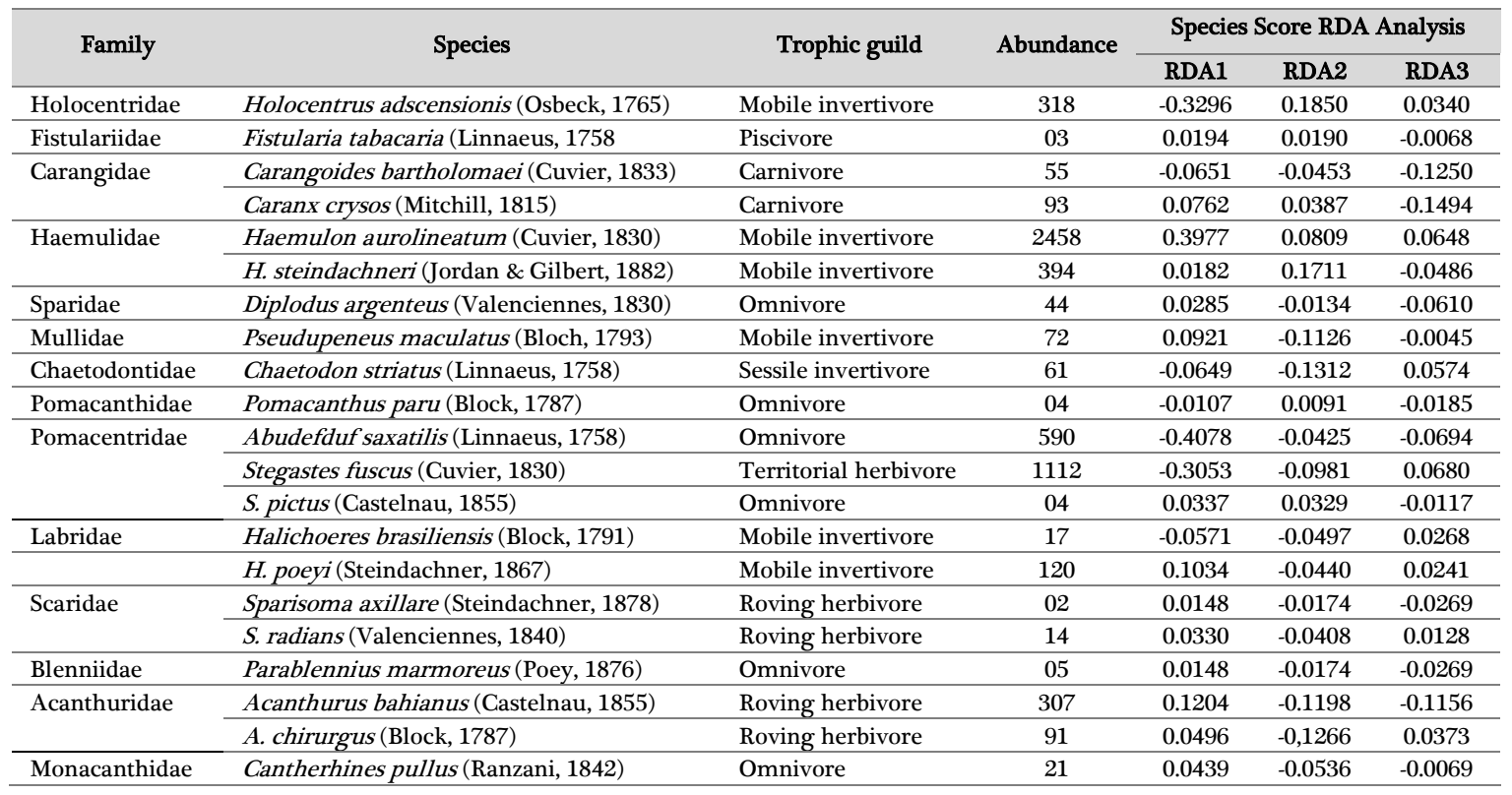

\section{Discussion}

This study shows that zoanthids (coverage mean of $45.66 \%$ ) and algae (coverage mean of $34.64 \%$ ) are the dominant elements of benthic coverage in this rocky shore ecosystem, being responsible for most of the variation revealed by our analysis. These results reinforce the importance of the role of competition for space between Palythoa caribaeorum (Pérez et al. 2005) (zoanthid) and algae in the structure of hard substrate ecosystems. This competition dynamic is directly associated with the recruitment success of the organisms that structure the substrate (Rabelo et al. 2007).

The recruitment success of these two substrate elements is related to reproductive and ecological features of these taxa. In addition to life traits, coverage proportion of these organisms at the substrate can be directly related to removal by other organisms, highlighting the role of trophic interactions as a top-down mechanism that controls the structure and dynamics of this habitat (Longo et al. 2015). Moreover, cnidarians are more disadvantaged competitors than algae at hard substrates due to their sensibility and reproductive biology (Tanner 1995). Birrell et al. (2005) proposed that settlement of coral and zoanthids species is slower in areas dominated by algae because of little free space and settlement inhibition. Thus, removal of one of these taxa (algae and zoanthids) promoted by biotic (foraging) and/or abiotic (wave action) factors, including anthropogenic factors, could induce the recruitment by other taxa (zoanthids and algae).

Further, the territorial and roving herbivores are of major importance for the structure and dynamics of benthic coverage by other organisms due to the greater recruitment potential presented by algae. Thus, the association of these fishes with habitats predominantly covered by algae is clear. Our study supports this hypothesis, since the herbivores $A$. bahianus and Acanthurus chirurgus (Block, 1787) presented preference for habitats with algae predominance. Although algae coverage was not included in our analysis (correlation with zoanthid coverage), 
the negative scores of these two species along the RDA 1 axis (species analysis) indicate a nonpreference for substrate covered by zoanthids, which means a preference for substrate covered by algae.

In addition, the roving herbivore trophic guild was composed by four more species. The Mugilidae Mugil curema (Valenciennes, 1836) presented relevant species score. The species $M$. curema is usually found in reef environments (Lieske \& Muers 1994), but only uses these areas as a passage to estuarine regions (Favero \& Dias 2015), which is in agreement with our observation of large schools during only one day. Despite $M$. curema abundance of more than 50 individuals, and its association to substrate covered by zoanthids, this relationship was probably biased due to the species' occasional presence on rocky shores.
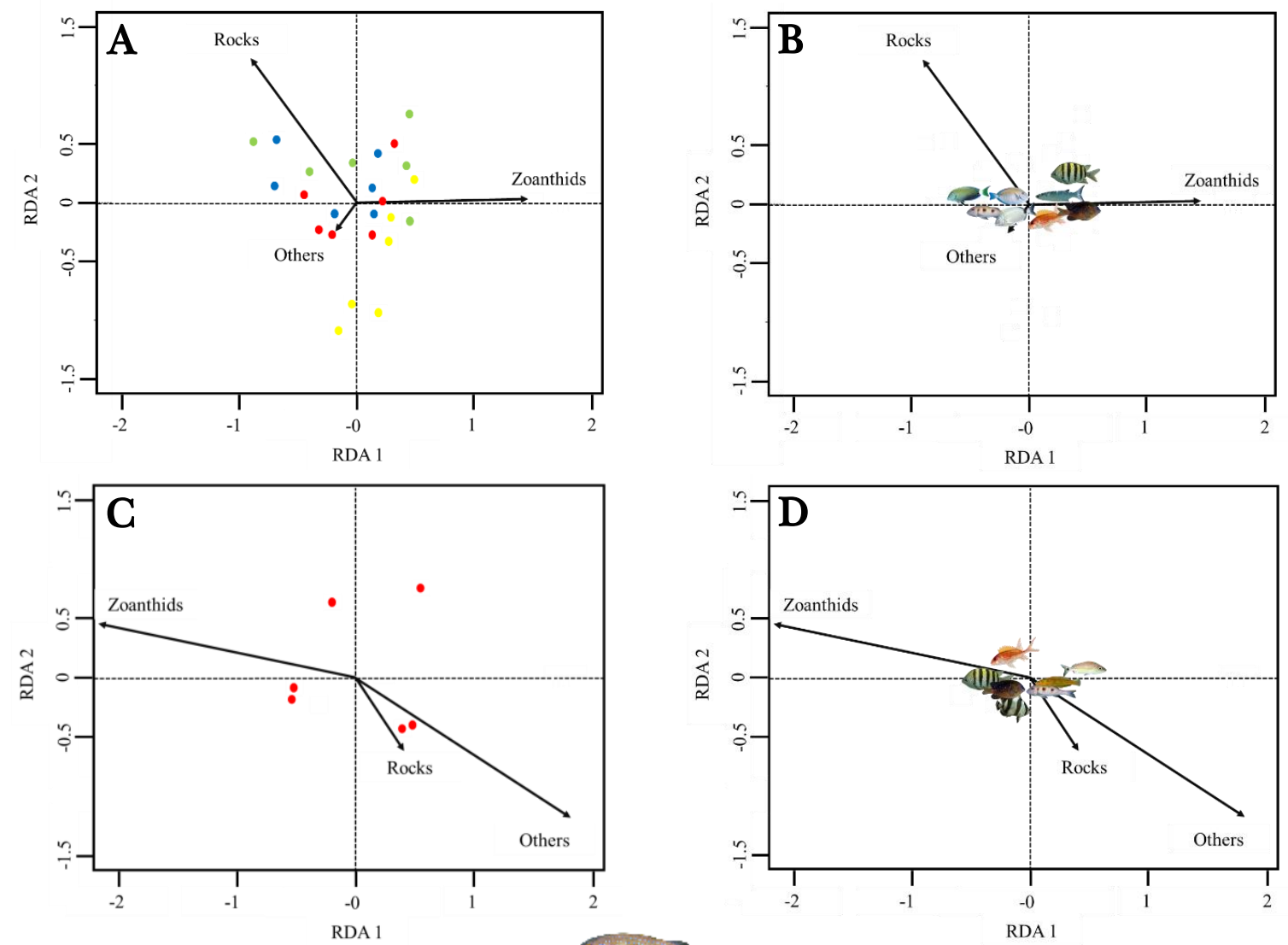

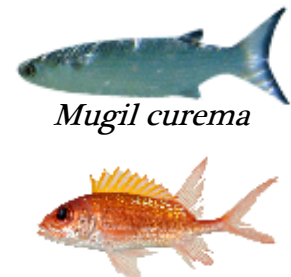

Holocentrus adscensionis
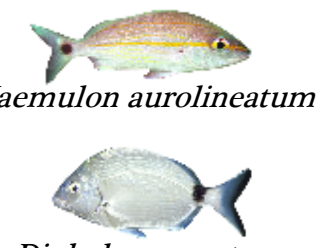

Diplodus argenteus

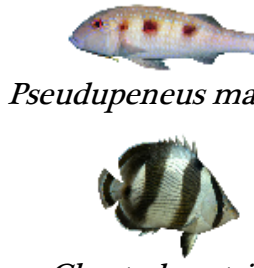

Chaetodon striatus

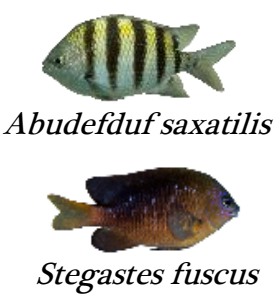

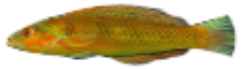

Halichoeres poeyi

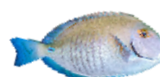

Acanthurus chirurgus

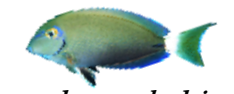

Acanthurus bahianus

Figure 4. RDA (Redundancy Analysis) analyses to investigate the relationship between substrate coverage and reef fish assemblage. Panels $\mathbf{A}$ and $\mathbf{C}$ (April) display vectors of influence for substrate coverage variables and sites scores. Panels B and D (April) display vectors of influence for substrate coverage variables and species scores (above 10). 


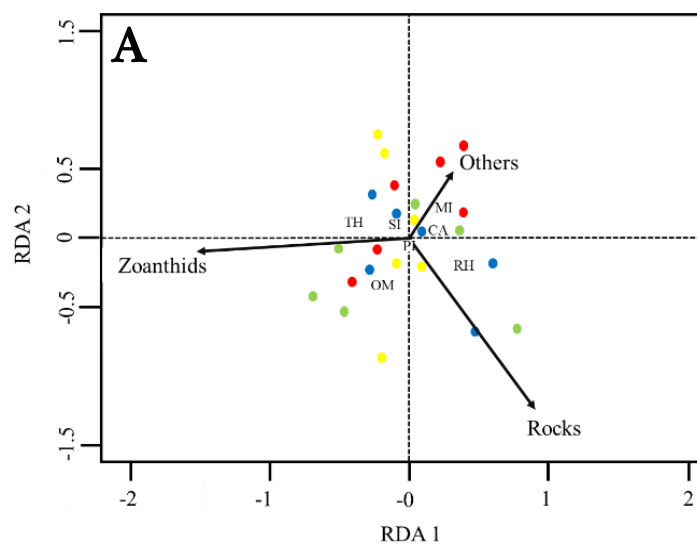

January March

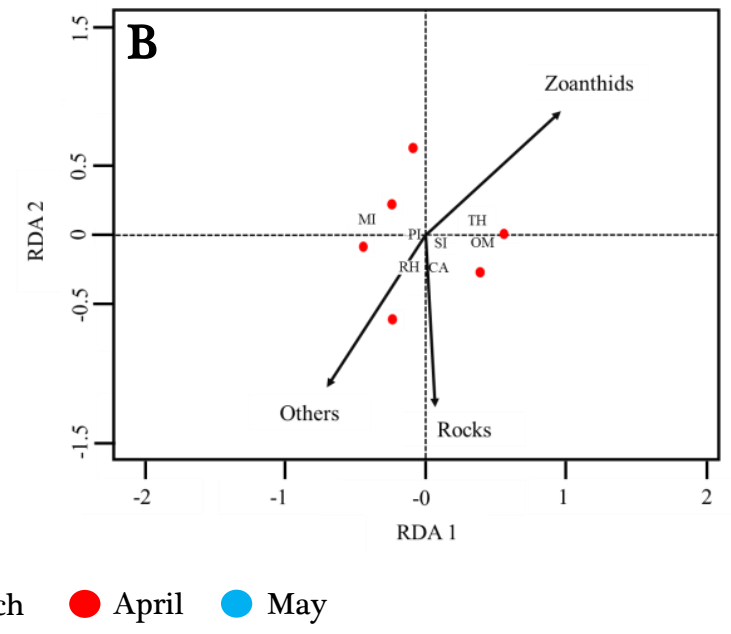

Figure 5. RDA (Redundancy Analysis) analyses to investigate the relationship between substrate coverage and reef fish guilds. Panels display vectors of influence for substrate coverage variables, sites scores and guilds scores. Carnivore (CA), territorial herbivore (TH), roving herbivore ( $\mathrm{RH}$ ), mobile invertivore (MI), sessile invertivore (SI), omnivore $(\mathrm{OM})$ and piscivore $(\mathrm{PI})$.

In contrast to other herbivores, the Pomacentridae S. fuscus (Cuvier, 1830) belongs to the guild of territorial herbivore. We observed the species' preference for a substrate predominantly covered by zoanthids. Although this species is herbivorous, it is extremely territorial, favoring habitats with sufficient algae banks for their feeding (Ferreira et al. 1998). This case can be interpreted as a strategy to avoid the attraction of competitors (Schacter et al. 2013). Our data corroborate this hypothesis, because areas predominantly covered by zoanthids are less attractive for roving herbivores. This strategy could be an advantage for $S$. fuscus (Cuvier, 1830) due to the lower competition for food resources. This species is the only representative of the territorial herbivore guild, thus the association of this trophic guild with the substrate resemble the observed association with $S$. fuscus.

The mobile invertivore guild establishes a strong association with patches of the rocky shore covered with algae. However, when we analyzed each species separately, this pattern was disrupted. Some species of this guild presented association with substrate predominantly covered by algae, $P$. maculatus (Bloch, 1793) and Halichoeres poeyi (Steindachner, 1867), zoanthids, $H$. adscensionis, others, $H$. steindachneri, and the species that did not show preference between these two coverages, $H$. aurolineatum.

The presence of mobile invertebrate feeders in transects with substrates predominantly covered by algae is explained by the dense coverage created by algae, harboring a great abundance of mobile invertebrates. These macroalgae offer a great amount of food resources and shelter against predation. However, substrates predominantly covered by zoanthids also shelter invertebrates because of the availability of refuges among the soft polyps of $P$. caribaeorum (Klumpp et al. 1988). This relationship could explain the presence of other reef fish species belonging to the mobile invertebrate guild.

Based solely on our data, we cannot assert the existence of differences in food resources availability among those habitats. Thus, an alternative hypothesis is needed to explain the preference of some species (e.g., $H$. adscensionis and $A$. saxatilis) for substrates predominantly covered by zoanthids. The presence of $H$. adscensionis on substrate with predominance of zoanthids is probablybiased by the sampling procedures, provided it is a nocturnal species (Greenfield 1981). During the observation, H. adscensionis individuals were often sheltered in caves since sampling was done during the day. The association between this species and this type of benthic coverage we observed probably coincides with the larger amount of shelter places found in these areas (Ferreira et al. 2004). 
The Pomacentridae $A$. saxatilis prefers substrates covered by zoanthids probably because this habitat offers a safety place for oviposition and predation avoidance. This species presents similar reproductive traits to $S$. fuscus such as mating in couples, demersal adhesives eggs attached to rocks, and male parental care (Bessa \& Sabino 2012). Habitats with predominance of zoanthids are more structuraly complex, offering more shelter places (Ferreira et al. 2004; Quadros et al. 2019). Furthermore, A. saxatilis individuals could benefit from S. fuscus's territorial protection, avoiding predation of adults and eggs by Serranidae e Labridae fishes (Randall 1967). This species represented 88\% of the entire abundance observed for the eight omnivore fish species observed, which explains the association of this guild with substrates covered by zoanthids.

The guild of sessile invertivore feeders was represented by Chaetodon striatus (Linnaeus, 1758) and Acanthostracion polygonius (Poey, 1876), but none of them showed preference for a substrate coverage, which was supported by a moderate association of this guild with two RDA axes. Because $C$. striatus accounts for $94 \%$ of this guild abundance, its substrate relationship could be characterized by this species behavior. The Chaetodontidae fishes are not considered selective feeders, their diet includes coral mucus and polyps, which include Palythoa sp. (zoanthid) (Bonaldo et al. 2005). Thus, the absence of preference for a substrate coverage could be justified by its generalist foraging.

The carnivorous fishes did not show a strong preference for any substrate coverage, both guild and species analyses. The guild presented a moderate association with two RDA axes, which were associated with rock (species score in RDA 2 axis -0.19) and others coverages. The species of this guild present different predation strategies, Caranx crysos (Mitchill, 1815) is a relatively specialist predator of some crustaceans and fishes of family Clupeidae (Sley et al. 2009) and Carangoides bartholomaei (Cuvier, 1833) is a generalist predator. Due to their diet be composed by mobile preys, theses fishes must forage a wide area, which allow these species to inhabit areas independent of the substrate coverage. Likewise, the piscivores, another predator guild feeding on high mobile preys, did not show evidence of a substrate coverage preference.

The temporal analysis did not allow us to evaluate the dynamics of the relationship between substrate coverage and fish assemblage. However, the results observed for the analysis in April, allowed us to verify the existence of changes in contrast with the entire period. The main change observed in April was the lower association of the roving herbivore guild with the substrate covered by algae. In April, we observed an increase on abundance of $H$. aurolineatum juveniles, which corresponded for $55 \%$ of the species total abundance. $H$. aurolineatum shows preference for substrates predominantly covered by algae because of their diet be based on mobile invertebrates, as observed for others mobile invertebrate feeders. Although, $H$. aurolineatum and roving herbivores fishes (e.g., A. bahianus) do not compete for the same food resource, they are foraging on the same area. Therefore, this singular increase on $H$. aurolineatum abundance could result in the decrease on the roving herbivore fish abundance. Thus, this juvenile recruitment highlights the importance that other ecological interactions, as interspecific competition, have on the structure and functional response of reef fish assemblage.

Although, it is widely recognizable that the reef fish assemblages of rocky shores are linked to the benthic communities inhabiting their substrates (Floeter et al. 2007; Medeiros et al. 2010; Krajewski \& Floeter 2011; Longo et al. 2015; Freitas et al. 2019; Quadros et al. 2019), our overall results suggest that the substrate composition has a low influence on fish assemblage structure. Both Redundancy analyses (RDA) of fish assemblages and trophic guild structure shown that our three substrate categories had low power to explain them $\left(\mathrm{R}^{2}\right.$ adjusted $=17.8 \%$ and $22.2 \%$ ).

In a study with parrotfishes at the Great Barrier Reef (Johnson et al. 2019), realized on a wider geographical range, $43.3 \%$ of the variance observed on this assemblage was explained (RDA analysis) by rocky shore topography (slope) and oceanographic characteristics (wave exposition, superficial water temperature). Another study, realized at Santa Lucia Island (Freitas et al. 2019), the reef fish assemblage variance was explained (62\%) by a set of 12 variables, highlighting the influence of substrate coverage composition. However, in addition to the wider 
geographical range of this study, the higher explanatory power of its RDA analysis is due to planktivore fishes being positively correlated with sites with a high cover of sand and macroalgae, a fish trophic guild and a substrate category not included in our study. Considering these studies, the low explanatory capacity presented by our set of variables could be related to the number of variables included in the analysis, as more substrate coverage categories, rocky shore topography and oceanographic characteristics. In addition, it should be noted that our study was carried out on a narrow geographical scale, focusing on a reef fish assemblage that inhabits the shallow waters of a rocky shores.

The structure and dynamics of reef fish assemblages that inhabit rocky shores are determined by abiotic and biotic features that set their influence on different geographical and temporal scales. Thus, the results of this study demonstrated that the habitat preference, characterized by benthic coverage, was important for the composition of reef fish assemblage on a micro-scale. This study showed that choice for a habitat among benthic coverage types could be explained by availability of food resources present at the habitat, also other biotic interactions that decrease the predation action.

\section{Acknowledgements}

We would like to thank the Universidade Federal do Estado do Rio de Janeiro (UNIRIO) for granted with student fellowships. We thank the colleagues Ana Clara S. Franco and Marcos de S. L. Figueiredo for helping us in the first version of this article in graduation course conclusion paper board, and the reviewers of this journal.

\section{References}

Acha E.M., Mianzan H.W., Guerrero R.A., Favero M. \& Bava J. (2004) Marine fronts at the continental shelves of austral South America: physical and ecological processes. Journal of Marine Systems, 44: 83-105. https://doi.org/10.1016/j.jmarsys.2003.09.005

Anderson A.B., Batista M.B., Gibran F.Z., Félix-Hackradt F.C., Hackradt C.W., García-Charton J.A. \& Floeter S.R. (2019) Habitat use of five key species of reef fish in rocky reef systems of southern Brazil: evidences of MPA effectiveness. Marine Biodiversity, 49: 1027-1036. https://doi.org/10.1007/s12526-018-0893-6

Batista D., Granthom-Costa L.V. \& Coutinho R. (2020) Biodiversidade Marinha dos Costões Rochosos de Arraial do Cabo: Histórico, Ecologia e Conservação. Arraial do Cabo: Instituto de Estudos do Mar Almirante Paulo Moreira. 407 p.

Bellwood D.R. \& Meyer C.P. (2009) Searching for heat in a marine biodiversity hotspot. Journal of Biogeography, 36: 569-576. https://doi.org/10.1111/j.1365-2699.2008.02029.x

Bessa E. \& Sabino J. (2012) Territorial hypothesis predicts the trade-off between reproductive opportunities and parental care in three species of damselfishes (Pomacentridae: Actinopterygii). Latin American Journal of Aquatic Research, 40(1): 134-141. https://doi.org/10.3856/vol40-issue1-fulltext-13

Birrell C.L., Mccook L.J. \& Willis B.L. (2005) Effects of algal turfs and sediment on coral settlement. Marine Pollution Bulletin, 51(1-4): 408-414. ttps://doi.org/10.1016/j.marpolbul.2004.10.022

Bonaldo R.M., Krajewski J.P. \& Sazima I. (2005) Meals for two: foraging activity of the butterflyfish Chaetodon striatus (perciformes) in southeast Brazil. Brazil Journal of Biology, 65: 211-215. https://doi.org/10.1590/S1519-69842005000200004

Chaves L.C.T., Nunes J.A.C.C. \& Sampaio C.L.S. (2010) Shallow reef fish communities of south Bahia coast, Brazil. Brazilian Journal of Oceanography, 58(special issue IICBBM): 33-46. http://dx.doi.org/10.1590/S1679-87592010000800006

Daros F.A., Bueno L.S., Vilar C.C., Passos A.C. \& Spach H.L. (2012) Checklist of rocky reef fishes from the Currais Archipelago and Itacolomis Island, Paraná state, Brazil. Check List, 8(3): 349-354. https://doi.org/10.15560/8.3.349 
Favero J.M. \& Dias J.F. (2015) Juvenile fish use of the shallow zone of beaches of the CananéiaIguape coastal system, southeastern Brazil. Brazilian Journal of Oceanography, 63(2): 103114. https://doi.org/10.1590/S1679-87592015081806302

Ferreira C.E.L., Gonçalves J.E.A., Coutinho R. \& Peret A.C. (1998) Herbivory by the Dusky Damselfish Stegastes fuscus (Cuvier, 1830) in a tropical rocky shore: effects on the benthic community. Journal of Experimental Marine Biology and Ecology, 229: 241-264. https://doi.org/10.1016/S0022-0981(98)00056-2

Ferreira C.E.L., Gonçalves J.E.A. \& Coutinho R. (2001) Community structure of fishes and habitat complexity on a tropical rocky shore. Environmental Biology of Fishes, 61: 353-369. https://doi.org/10.1023/A:1011609617330

Ferreira C.E.L., Floeter S.R., Gasparini J.L., Ferreira B.P. \& Joyeux J.C. (2004) Trophic structure patterns of Brazilian reef fishes: a latitudinal comparison. Journal of Biogeography, 31: 10931106. https://doi.org/10.1111/j.1365-2699.2004.01044.x

Floeter S.R., Behrens M.D., Ferreira C.E.L., Paddack M.J. \& Horn M.H. (2005) Geographical gradients of marine herbivorous fishes: patterns and processes. Marine Biology, 147: 14351447. https://doi.org/10.1007/s00227-005-0027-0

Floeter S.R., Krohling W., Gasparini J.L., Ferreira C.E.L. \& Zalmon I.R. (2007) Reef fish community structure on coastal islands of southeastern Brazil: the influence of exposure and benthic cover. Environmental Biology of Fishes, 78: 147-160. https://doi.org/10.1007/s10641006-9084-6

Fortes R.R. \& Absalão R.S. (2010) The latitudinal and bathymetric ranges of marine fishes: a global analysis to test the application of Rapoport's Rule. Marine Ecology, 31: 483-493. https://doi.org/10.1111/j.1439-0485.2010.00357.x

Freitas R., Mendes T.C., Almeida C., Melo T., Villaça R.C., Noguchi R., Floeter S.R., Rangel C.A. \& Ferreira C.E.L. (2019) Reef fish and benthic community structures of the Santa Luzia Marine Reserve in the Cabo Verde islands, eastern central Atlantic Ocean. African Journal of Marine Science, 41(2): 177-190. https://doi.org/10.2989/1814232X.2019.1616613

Fulton C.J. \& Bellwood D.R. (2004) Wave exposure, swimming performance, and the structure of tropical and temperate reef fish assemblages. Marine Biology, 144: 429-437. https://doi.org/10.1007/s00227-003-1216-3

Gil M.A., Renfro B., Figueroa-Zavala B., Penié I. \& Dunton K.H. (2015) Rapid tourism growth and declining coral reefs in Akumal, Mexico. Marine Biology, 162: 2225-2233. https://doi.org/10.1007/s00227-015-2748-z

Gonzales-Rodriguez E., Valentin J.L., André D.L. \& Jacob S.A. (1992) Upwelling and downwelling at Cabo Frio (Brazil): comparison of biomass and primary production responses. Journal of Plankton Research, 14(2): 289-306. https://oi.org/10.1093/plankt/14.2.289

Grafeld S., Oleson K., Barnes M., Peng M., Chan C. \& Weijerman M. (2016) Divers' willingness to pay for improved coral reef conditions in Guam: An untapped source of funding for management and conservation? Ecological Economics, 128: 202-213. https://doi.org/10.1016/j.ecolecon.2016.05.005

Graham N.A., Bellwood D.R., Cinner J.E., Hughes T.P., Norström A.V. \& Nyström M. (2013) Managing resilience to reverse phase shifts in coral reefs. Frontiers in Ecology and the Environment, 11: 541-548. https://doi.org/10.1890/120305

Greenfield D.W. (1981) Holocentridae (p. 213-222). In: Fischer W., Bianchiand G. \& Scott W.B. (Eds). FAO species identification sheets for fishery purposes. Eastern Central Atlantic. Fishing areas. Volume 2. Rome: Department of Fisheries and Oceans Canada and FAO. 324 p.

Johnson G.B., Taylor B.M., Robbins W.D., Franklin E.C., Toonen R., Bowen B. \& Choat J.H. (2019) Diversity and Structure of Parrotfish Assemblages across the Northern Great Barrier Reef. Diversity, 11: 1-14. https://doi.org/10.3390/d11010014

Klumpp D.W., Mckinnon A.D. \& Mundy C.N. (1988) Motile cryptofauna of a coral reef: abundance distribution and trophic potential. Marine Ecology Progress Series, 45: 95-108. 
Kohler K.E. \& Gill S.M. (2006) Coral Point Count with Excel extensions (CPCe): A Visual Basic program for the determination of coral and substrate coverage using random point count methodology. Computers and Geoscience, 32(9): 1259-1269.

https://doi.org/10.1016/j.cageo.2005.11.009

Kraines S.B., Isobe M. \& Komiyama H. (2001) Seasonal variations in the exchange of water and water-borne particles at Majuro Atoll, the Republic of the Marshall Islands. Coral Reefs, 20(4): 330-340. https://doi.org/10.1007/s00338-001-0191-8

Krajewski J.P. \& Floeter S.R. (2011) Reef fish community structure of the Fernando de Noronha Archipelago (Equatorial Western Atlantic): the influence of exposure and benthic composition. Environmental Biology of Fishes, 92: 25-40. https://doi.org/10.1007/s10641-0119813-3

Lieske E. \& Myers R. (1994) Collins Pocket Guide. Coral reef fishes. Indo-Pacific \& Caribbean including the Red Sea. New York: Haper Collins Publishers. $400 \mathrm{p}$.

Lima L.F.O. \& Coutinho R. (2016) The reef coral Siderastrea stellata thriving at its range limit: population structure in Arraial do Cabo, southeastern Brazil. Bulletin of Marine Science, 92(1): 107-121. http://doi.org/10.5343/bms.2015.1029

Longo G.O., Morais R.A., Martins C.D.L., Mendes T.C., Aued A.W., Cândido D.V., Oliveira A.J.C., Nunes L.T., Fontoura L., Sissini M.N., Teschima M.M., Silva M.B., Ramlov F., Gouvea L.P., Ferreira C.E.L., Segal B., Horta P.A. \& Floeter S.R. (2015) Between-Habitat Variation of Benthic Cover, Reef Fish Assemblage and Feeding Pressure on the Benthos at the Only Atoll in South Atlantic: Rocas Atoll, NE Brazil. PlosOne, 10(6): 1-29. http://doi.org/10.1371/journal.pone.0127176

McClanahan T. \& Karnauskas M. (2011) Relationships between benthic cover, current strength, herbivory, and a fisheries closure in Glovers Reef Atoll, Belize. Coral Reefs, 30(1): 9-19. http://doi.org/10.1007/s00338-010-0690-6

Medeiros P.R., Souza A.T. \& Ilarri M.L. (2010) Habitat use and behavioural ecology of the juveniles of two sympatric damselfishes (Actinopterygii: Pomacentridae) in the south-western Atlantic Ocean. Journal of Fish Biology, 77: 1599-1615.

MMA (2002) Ministério do Meio Ambiente / Relatório Técnico - Avaliação e Ações Prioritárias para a Conservação da Biodiversidade das Zonas Costeira e Marinha. Disponível em: http://rodadas.anp.gov.br/arquivos/Round8/sismica_R8/Bibliografia/MMA2002.PDF (Acesso em: 02/05/2020).

MMA (2019) Ministério do Meio Ambiente / ICMBio - Instituto Chico Mendes. Plano de Ação Nacional para Conservação de Ambientes Coralíneos (PAN Corais). Disponível em: http://www.icmbio.gov.br/portal/faunabrasileira/planos-de-acao-nacional (Acesso em: $02 / 05 / 2020)$.

Moreno T.R. \& Rocha R.M.D.A. (2012) Ecologia de costões rochosos. Estudos de Biologia, 34(83): 191-201. http://doi.org/10.7213/estud.biol.7332

Mumby P.J., Steneck R.S., Edwards A.J., Ferrari R., Harborne A.R., Coleman R. \& Gibson J. (2012) Fishing down a Caribbean food web relaxes trophic cascades. Marine Ecology Progress Series, 445: 13-24. https://doi.org/10.3354/meps09450

Nelson J.S., Grande T.C. \& Wilson M.V.H. (2006) Fishes of the World. $4^{\circ}$ edition. Hoboken: John Wiley and Sons. $622 \mathrm{p}$.

Oksanen J.F., Blanchet G., Kindt R., Legendre P., Minchin P.R., O'Hara R.B. \& Wagner H. (2013) Vegan: community ecology package. Retrieved from http://CRAN.R-project.org/packa ge=vegan

Pérez C.D., Vila-Nova D.A. \& Santos A.M. (2005) Associated community with the zoanthid Palythoa caribaeorum (Duchassaing \& Michelotti, 1860) (Cnidaria, Anthozoa) from littoral of Pernambuco, Brazil. Hydrobiologia, 548: 207. https://doi.org/10.1007/s10750-005-5441-2

Quantum Gis (2020) QGIS Geographic Information System. Open Source Geospatial Foundation Project. http://qgis.org 
Quadros A.L.S., Barros F., Blumstein D.T., Meira V.H. \& Nune J.A.C.C. (2019) Structural complexity but not territory sizes influences flight initiation distance in a damselfish. Marine Biology, 166: 65. https://doi.org/10.1007/s00227-019-3508-2

Rabelo E.F. (2007) Distribuição espacial e interações competitivas em zoantídeos (Cnidaria: Zoanthidae) em um ambiente de recifes de arenito nos recifes do Brasil. Dissertação (Programa de Pós-Graduação em Ciências Marinhas Tropicias). Universidade Federal do Ceará, Instituto de Ciências do Mar, Fortaleza.

Randall J.E. (1967) Food habits of reef fishes of the West Indies. Studies in Tropical Oceanography, 5: 665-847.

R Core Team (2019) R: A language and environment for statistical computing. Vienna, Austria: R Foundation for Statistical Computing. Retrieved from https:/www.R-project.org/

Roberts D.W. (2019). Labdsv: Ordination and Multivariate Analysis for Ecology. Retrieved from https://CRAN.R-project.org/package=labdsv

Schacter C.R., Albright L.B., Dubofsky E.A., Fitzsimmons J.N., Focht R., Nadler L.E., Sandercock M., Taylor L., Walfoort D., Whitten T., Williams L.J. \& Rosenthal G.G. (2013) Risk-sensitive resource defense in a territorial reef fish. Environmental Biology of Fish, 96(9): 813-819. https://doi.org/10.1007/s10641-013-0181-z

Sivaperuman C., Velmurugan A., Singh V.A. \& Jaisankar I. (2018) Biodiversity and Climate Change Adaptation in Tropical Islands. Amsterdam and New York: Academic Press. 805 p.

Sley A., Jarboui O., Ghorbel M. \& Bouain A. (2009) Food and feeding habits of Caranx crysos from the Gulf of Gabès (Tunisia). Journal of the Marine Biological Association of the United Kingdom, 89(7): 1375-1380. https://doi.org/10.1017/S0025315409000265

Spalding M.D., Fox H.E., Allen G.R., Davidson N., Ferdana Z.A., Finlayson M., Halpern B.S., Jorge M.A., Lombana A., Lourie S.A., Martin K.D., Mcmanus E., Molnar J., Recchia C.A. \& Robertson J. (2007) Marine ecoregions of the world: a bioregionalisation of coastal and shelf areas. BioScience, 57: 573-583. https://doi.org/10.1641/B570707

Tanner J.E. (1995) Competition between scleractinian corals and macroalgae: An experimental investigation of coral growth, survival and reproduction. Journal of Experimental Marine Biology and Ecology, 190: 151-168. https://doi.org/10.1016/0022-0981(95)00027-O

Zuur A.F., Ieno E.N. \& Elphick C.S. (2010) A protocol for data exploration to avoid common statistical problems. Methods in Ecology and Evolution, 1: 3-14. https://doi.org/10.1111/j.2041210X.2009.00001.x 